JOURNAL OF SECURITY AND SUSTAINABILITY ISSUES

ISSN 2029-7017 print/ISSN 2029-7025 online

2021 Volume 11

https://doi.org/10.47459/jssi.2021.11.12

\title{
THE SYSTEM OF DEFENCE EDUCATION SYSTEM FOR POLISH YOUTH AFTER 1989 AND ITS TRANSFORMATIONS
}

\author{
Andrzej Soboń1, Ilona Urych ${ }^{2}$ \\ 1,2Faculty of National Security, War Studies University, 00-910 Warsaw, al. Chrusciela 103, Poland \\ E-mails: ${ }^{1}$ a.sobon@akademia.mil.pl; ${ }^{2}$.urych@akademia.mil.pl
}

Received 15 January 2021; accepted 15 April, 2021; published 30 June 2021

\begin{abstract}
The objective of this article is to describe the system of defence education for Polish youth after 1989 and its transformations. The article indicates that in Polish primary and secondary schools today, the subject of security education is taught, and in some high schools - especially in Certified Military Uniformed Classes - the subject of military education is taught as well. Among students, however, the defence curriculum is taught mainly as part of extra-curricular activities, mainly within the Academic Legion and Passport Programme. On the basis of the research strengthening military potential is supported by the defence education of young people. The exploration underlined that achieving the defence objectives outlined by the programmes of the Ministry of National Defence in agreement with the Ministry of National Education. The study used the diagnostic survey research method and the techniques of content analysis, a questionnaire, interviews, and observations. The article conluds recommendations for security education curriculum.
\end{abstract}

Keywords: security, defence education, security education, uniformed classes, military classes, military training

Reference to this paper should be made as follows: Soboń, A., Urych, I., 2021. The system of defence education system for Polish youth after 1989 and its transformations. Journal of Security and Sustainability Issues, 11, 159-168, https://doi.org/10.47459/jssi.2021.11.12

JEL Classifications: F52, I260, H760

Additional disciplines: political sciences, military sciences, law, education.

\section{Introduction}

In the filed of the system of defence education system have been explored too benefits of social capital (Laužikas, Dailydaitė 2013; Soboń 2017; Tumalavičius et al. 2020; Kwaśniak, Wojciszko 2014; Loshytskyi et al., 2020; Urych 2020) or the role of leadership in motivating (Diskienè, Paulienè 2018; Grenčíková et al. 2017). Research shows that sustainable funcioning are very important (Islamgaleyev et al. 2020), so in the unstable international security environment, Poland is obliged to shape its defence system in such a manner that promotes the security of its citizens. Threats to the security of the Republic of Poland (Gryz 2004) largely result from the complexity of contemporary threats and their mutual penetration into each sphere of state activity, not only in the internal dimension, but also in international relations. Against this background, the list of dangers has the character of common internal threats to Poland, the European Union and NATO (Loshytskyi et al. 2020). Our country's participation in the structures of NATO, the OSCE, the UN, the EU or the Visegrad Group is in essence to strengthen Poland's security, as exemplified by the Common Security and Defence Policy. One element of these associations is the need for systematic cooperation in the area of planning and preparation of national defence. Thus, domains of national defence preparations include specific tasks and areas of interest. On the other hand, one functional domain of national defence preparations that can be highlighted is that of education (Sobon 2017). Education in this field includes the activities of the state in the area of national defence preparations, the primary purpose of which is to shape defence awareness in society (Kwaśniak, Wojciszko 2014). 
Education - as the basis for the existence and development of the state - preordains its strength, advantages, opportunities or the lack of them, and creates in society a sense of community within the state and in military and economic alliances (Cackowski 1999). Education also includes issues related to defence in the areas of national defence preparations, the armed forces, as well as the organisation and conduct of defence activities in their military and non-military dimensions. In turn, its contemporary dimension, security education, includes the scope of knowledge indicated by the discipline of security sciences (M.P. 2011 No. 14 item 149). An attribute of these sciences is their practical dimension, which results from the fact that the subject of research is related to the changing nature of threats (Gryz 2004).

Defence education brings about a change in awareness in society and along with it the need to build powerful armed forces based not solely on participation in the NATO military alliance (Tumalavičius et al. 2020). Esence education on the example within the Lithuanian and Austrian Armed Forces analized Hurbišová and Davidova (Hurbišová, Davidová 2016). While in Poland contemporary youth defence education is mainly implemented within the framework of security education and other brief forms of defence training, such as the Academic Legion and the Passport Programme (Soboń 2018).

The objective of this article is to describe the system of defence education for Polish youth after 1989 and its transformations. The research problem of the study was expressed in the following question: What characterises the system of defensive education for Polish youth after 1989 and what are its transformations? The answer to the main question of this narrative was provided through analysis of the literature on defence education in Poland and analysing the results of empirical studies. The study used the method of diagnostic survey and the techniques of content analysis, a questionnaire, interviews, and observations. The main inspiration for the article was provided by the projects of the Ministry of National Defence conducted jointly with the War Studies University as part of their support of defence education in Poland.

The article presents military education in Poland after 1989, which formally has been associated primarily with the change of the subject of civil defence training into the subject of security education. It then discusses the contemporary characteristics of military education in Polish secondary schools as taught in Certified Military Uniformed Classes. Then the article presents other forms of military education in Poland, such as the Academic Legion and Passport Programme. The article ends with conclusions and recommendations.

\section{Defence education after 1989 - changing civil defence training into security education}

The social and political transformations in Poland after 1989 - primarily associated with the change of the communist system to a democratic one - resulted in changes in the defence education of young people. Until that time, schools had taught civil defence training. The primary objective of this subject was to prepare young people to defend themselves against the dangers of wartime and other threats, as well as to lead small civil defence teams. Civil defence training also fulfilled the role of patriotic and defence education, but it did have an ideological foundation. Since there were political connotations in this subject, in 1990 military preparation of school-age youth was abandoned, and the subject of civil defence training was withdrawn from primary schools. Issues of common self-defence were introduced, the actual implementation of which turned out to be illusory and ineffective due to the lack of appropriate legal regulations and proper organisation by most school directors. In secondary schools, new programmes of civil defence training were introduced, with the content relating exclusively to the protection of health and life in the case of threats in peacetime. In 1991 military classes were also removed from university curricula (Kaliński 2005).

An important legal basis in that period was Regulation No. 36 of the Minister of National Education of 29 October 1992 on the types of schools in which students are obliged to undergo civil defence training and the principles for the organisation of civil defence training classes in schools (Journal of Laws of the Ministry of Education No. 8 item 38). This document was a response to a growing demand for the introduction of curricular and organisational changes in the area of defence education for students in public and private secondary schools. This resulted, among other factors, from the growing popularity of shooting tournaments, sports- 
defence tournaments and Civil Defence knowledge tournaments. The pro-defence events organised at that time made it possible to popularise knowledge of national defence and the Polish Armed Forces among school-age children and youth, to encourage them to improve their physical fitness, to compete in shooting sports, to teach good habits and skills in providing first aid in emergencies, to spread knowledge of road traffic regulations, and above all to shape pro-defence attitudes to counter real and potential threats. The "Silver Musket" shooting tournaments and "Fit as Soldiers" sports-defence tournaments are still organised today. Until the educational reform of 1999, the programme of civil defence training secondary schools consisted of 76 hours over two years of education - one hour per week in years one and two (Araucz-Boruc 2015). In turn, the assumptions of the introduced reform concerned the formation of society's ability to cope with various types of security threats, as well as the ability to survive in such situations. In turn, the principles of the introduced reform concerned the formation of society's ability to cope with various types of security threats, as well as the ability to survive in such situations (Pieczywok 2012).

In 2002, another regulation was introduced on the types of schools in which students are subject to obligatory civil defence training and the organisation of such training (Journal of Laws 2002, No. 113, item 987). In accordance with this regulation, students of public and private secondary schools, i.e.: basic vocational schools, general secondary schools, specialised secondary schools and technical secondary schools were subject to obligatory civil defence training. This was implemented in the form of one hour of classroom instruction per week in years one and two. The regulation also stipulated obligatory training in first aid, field studies and sport shooting. Moreover, during holiday breaks, first year students could participate in special training and recreation camps in civil defence training according to the principles defined in the regulations on the organisation of recreation for children and school-age youth. The change in the type of non-military threats and the simultaneous increase of factors causing a direct threat to human life and health, as well as to public safety and national security made it necessary to introduce further modifications to the curricula and organisational framework of defence education (Urych 2019).

On 1 September 2009, the Ministry of National Education, in agreement with the Ministry of National Defence, introduced a new subject to the core curriculum of middle schools and upper secondary schools, security education, replacing the former one, civil defence training (Journal of Laws 2009 No. 139, item 1131). It was decided to introduce security education in all stages of teaching, and for students in military-profiled classes also military training.

Article 166 of the Act of 21 November 1967 on the Universal Duty to Defend the Republic of Poland (Journal of Laws 2017, item 60) states that "students of elementary schools and secondary schools: general secondary schools, technical schools and first-degree trade schools, with the exception of students of schools for adults, are subject to obligatory security education". On this basis, in accordance with the Regulation of the Minister of National Education of 14 February 2017 on the core curriculum for pre-school education and the core general education primary school curriculum, including for students with moderate or severe intellectual disabilities, general education for first-degree trade schools, general education for special job training schools and general education for post-secondary schools (Journal of Laws 2017, item 356), starting in the 2019/2020 school year, the subject of security education was to prepare students theoretically and practically to behave appropriately and react appropriately in difficult and crisis situations that pose a threat to health and life. The subject covered a variety of educational content in the following areas: national security (four hours), organisation of rescue operations (seven hours of instruction), health education (seven hours per year) and first aid (10 hours of instruction). The legislator pointed out that it was important for the teacher to focus on practice when teaching the subject, especially when teaching first aid, developing appropriate reflex reactions in the event of a real danger and conducting a rescue operation. In this way, emphasis was placed on acquiring the ability to cope with a wide range of threats different than the typical external threats. The reform introduced the subject not only in secondary school, but also made one hour per week obligatory in the eighth grade of primary school.

Following Janusz Ropski (Ropski 2015), it should be indicated that the term "security education" appeared in the course of research on the security system of the Republic of Poland, conducted at the National Defence 
Academy in the 1990s. In those years, significant changes arose in the interpretation of what had traditionally been understood as defence education of society, which made it possible to replace it with the term "security education". While Ilona Urych (2019a) indicates that "In the area of program changes in the contents of the subject, [security education] has departed from security as traditionally understood, associated with the ability to counter external threats, usually identified with warfare. Nowadays, it seems more important to educate people in coping with many threats that do not have the characteristics of typical external threats. The direction of education has been transferred from the pro-defense content to general safety and preparation in the event of threats to life and health". The subject of security education is connected with patriotic, civic, moral and defence education. As a component of general education, it is supposed to direct and integrate those educational efforts that foster the formation of patriotic and pro-defence attitudes (Urych 2020).

The present-day curriculum of security education also appears in higher education in such fields of study as national security, internal security, security engineering or European studies. Security education is also the subject of many postgraduate studies (adult education), specialist and qualification courses (in-service training and continuing education). The subject also appears in doctoral studies in the field of security. Security education as curriculum content taught at different levels of institutional and non-institutional education in Poland serves to prepare society to act in support of security - individual, social and national (Diskienè 2018; Smaliukiene 2019; Urych 2020).

In conclusion, it should be stated that "[security education] is a continuous process involving a range of activities in the upbringing and education of young people in particular, including the transmission of knowledge, the formation of attitudes and the development of personality in order to function effectively in the event of various threats, as well as to protect health every day" (Urych 2020; Smaliukiene et al. 2020; Diskiené, Paulienè 2018).

\section{Contemporary military education in Polish secondary schools - Certified Military Uniformed Classes}

Contemporary defence education for Polish youth is also realised within the framework of military education, which takes place in Certified Military Uniformed Classes. This is because the aim of the subject of security education is to prepare students in theory and in practice to behave properly in difficult crisis situations that pose a threat to health and life. However, the programme does not include a typically military content. Moreover, the Ministry of National Education stipulated 30 hours for this subject in the core curriculum (one hour per week). Therefore, a specific extension of the content of the subject of security education are programmes of class groups with a uniformed services profile, offering innovative didactic objectives in the area of defence education for young people. The popularity of these classes, combined with a variety of additional activities, such as parachute training, scuba diving, or qualified medical assistance, is conducive to achieving the objectives of defence education. The effective realisation of these goals largely depends on cooperation with military institutions and units. Therefore, in order to support this manner of defence education for young people, the Ministry of National Defence, in agreement with the Ministry of National Education, introduced the "Programme for supporting secondary schools operating Certified Military Uniformed Classes". The Programme is implemented with the support of military units, training centres and the appropriate Territorial Military Administration Authorities for the schools.

The programme of Certified Military Uniformed Classes Program totals 185 hours o instruction (theoretical and practical), realised in the subject of military education, including:

(1) 45 hours of theoretical instruction in school;

(2) 90 hours of practical instruction with a military unit;

(3) 50 hours of practical instruction realised as part of military training in the form of a training camp;

(4) 30 hours of self-study.

An important element in the implementation of the programme is the support of Territorial Military Administration Authorities in guiding willing students to possible career paths in military service and the military 
qualification of adult students - volunteers during the summer holidays after graduation, culminating in taking the oath of military service (Urych 2020).

The authors of this article took part in the first stage of the Programme and from 1 September 2017 to 31 January 2019 supervised the course of the educational process of students in uniformed classes realised as part of the subject of military education in five secondary schools. The observations were carried out at:

(1) The LI Tadeusz Kosciuszko Comprehensive High School in Warsaw,

(2) The Comprehensive High School of the Professional Education Institute in Giżycko,

(3) The Comprehensive High School of the Nauka Education Centre Sp. z o.o. in Piła,

(4) The Complex of Schools and Educational Facilities in Skala,

(5) The Complex of Secondary Schools No. 1 in Kłodzko. In the study of the effectiveness of education, the diagnostic survey method was used, the technique was a survey and interviews, and the research tools were a survey questionnaire and an interview questionnaire (Pilch 1999).

A written questionnaire was used to survey students. On the other hand, military instructors, school principals and teachers in the observed schools were surveyed using an interview questionnaire.

The analysis of the survey results showed that according to the military instructors, there needs to be the possibility to modify the programme depending on the students' abilities. According to the respondents it would be good if the programme did not strictly define the content, but only thematic blocks that would define the framework and objectives. Moreover, it would be helpful to specify the documents that the unit should have, e.g. the military should have a clear record of who pays for food and accommodation during the camp. It would also be a good idea for a representative of the Ministry of Defence to familiarise military instructors with the content of the programme and to ask military units about what their needs may be before proceeding.

Furthermore, according to the surveyed military instructors, soldiers have purely military competences, but none in teaching methodology. It should therefore also be emphasised that there is a need for instruction in teaching methodology or the possibility to take part in a pedagogical course for conducting classes with students. Moreover, there is a need for support from the Ministry of National Defence for the implementation of the Programme, e.g. in a situation when a unit cannot carry out the training on a given day or assigning these classes to another military unit.

In the opinion of school directors and the teachers responsible for the programme, the objectives, content, Programme layout, division into subjects, number of hours, selection of the forms and methods of teaching are appropriate for the needs and abilities of students and are in line with the needs of the Polish Armed Forces. The assessment of technical conditions (technical equipment, classrooms, teaching aids) is positive, as they are appropriate for the content of the training and needs in this area. The fact that some classes are conducted in school and some with a military unit deserves praise. On the other hand - in the opinion of these respondents it is difficult to assess the usefulness of the Programme today.

According to the respondents, cooperation between the school and the affiliated military unit is very good. The students' supervisor is in constant contact with those persons responsible for the organisation of classes. Schools cooperate with military units, but also with the Pro-Defence Bureau of the Ministry of Defence and the War Studies University. The institutions designated to support the subject of military education support the implementation of the Programme very well.

In the opinion of school directors and teachers responsible for the implementation of the Programme, changes in the subject of military education could concern a cyclical schedule of subjects. The subject should be regulated by law, synchronised with school documentation, permanently inscribed in an executive act, taking into account, among other things, the rules for recruitment, the objectives and programmes of the school. 
The respondents also pointed out that the coordinating teacher, one who conducts theoretical classes, due to the necessity of having many competences, could be additionally employed as part of the project. In the current situation, the teacher should only be a coordinator and all classes, including theoretical ones, should be conducted by representatives of the partner organisations. One suggestion was to concentrate the military training days to two per month or to consider concentrating the content in the second year of high school in May and June, when the graduating classes are leaving school.

In the opinion of school directors and teachers, materials addressed to teachers and students such as "The shooter's handbook" and "Pro-defence - territorial" are useful and support the realisation of the subject of military education. However, there is a need to support the e-learning platform, which needs to be enriched with substantive content.

During each expert visit, conducted as part of the military training days, students participating in the Certified Military Uniformed Classes Programme were also asked for their opinions on the subject. The research was carried out by means of anonymous written questionnaires.

On the basis of this survey, it can be concluded that in the opinion of all the students surveyed:

(1) The aims, objectives and course of the subject of military education are unambiguous, clear and understandable (strongly agree $-81 \%$, agree $-19 \%$ );

(2) The subject matter in military education corresponds to their expectations (56\%, including strongly agree $-44 \%$, agree $-56 \%$ );

(3) There is good access to information regarding the training programme (strongly agree $-31 \%$, agree $59 \%$;

(4) Classes took place regularly and for the full amount of time (strongly agree $-94 \%$, agree $-6 \%$ );

(5) Classes to a great extent contributed to learning the necessary knowledge, abilities and attitudes (strongly agree $-44 \%$, agree $-56 \%$ );

(6) Teachers evaluated and discussed errors and indicated the correct way to perform the task (strongly agree $-88 \%$, agree $-12 \%)$;

(7) The use of the equipment, armament, ammunition, elements of battlefield simulation and others were made available for use (strongly agree $-69 \%$, agree $-31 \%$ ).

It is noteworthy that the entire group of respondents $(100 \%)$ stated that the instructors provided their own materials to consolidate or expand their knowledge and skills.

Moreover, analysis of the results of the research conducted by the authors by means of observation indicates that the subject of military education supported by military units is an innovative curricular and methodical solution, that yields strong effects of defence education. Practical training in military education in secondary schools takes place with military units and at training centres in the form of military training days, i.e. practical classes in the field with military and specialist equipment. Thus, this subject can form the foundation for a career path in the Polish Armed Forces.

\section{Other forms of defence education in Poland - the Academic Legion and the Passport Programme}

The creation of non-commissioned officer and officer reserves was reintroduced by the Ministry of National Defence in Poland in 2017 as an idea for voluntary student training called the Academic Legion. The project is a continuation of the historical student military formation that was formed on 11 November 1918 at Warsaw universities. The defence training in the Academic Legion programme is divided into theoretical and practical parts. The theoretical part is carried out at universities. The practical part is realised in centres, training institutes and military units (Wojsko 2020). 
The theoretical part of the voluntary student training in the Academic Legion consists of 30 hours of instruction during the academic year, but outside of the ordinary curriculum, covering subjects in the field of defence and military knowledge. The theoretical part consists of the following thematic blocks: Topography; Basic Information about the Polish Armed Forces; Principles of safety in firearm training; Basic concepts and theory of shooting; Principles of aiming and firing a shot; Improving fire - methods and principles; Construction, purpose, and combat characteristics of firearms, ammunition and hand grenades; Purpose, construction and basic technical and tactical data of the Model 96 Beryl assault rifle; Types of ammunition and cartridge construction; Types and construction of hand grenades and fuses; General principles of AAW; Common warning and alarm signals; Actions by soldiers after an air alarm; Types and classifications of explosives and incendiary devices; Methods of initiation of explosion by flame; Electrical methods of initiation of explosion; Non-electrical methods of initiation of explosion - STS; Safety rules for the handling of explosive ordinance; Equipment for contamination reconnaissance, Individual protection against contamination, Flares and smoke grenades; Military ranks; Principles of the duties of a soldier; Provision of first aid; Provision of first aid on the battlefield; Organisation and security of communication and basic regulations of radio communication; Radio data table; Characteristics of the basic means of communication at the sub-subunit level; Protection of classified information; Military regulations; Methodology of military training; International Humanitarian Law of Armed Conflicts; Civic education; Prevention and military discipline (Program 2020/21).

After passing the theoretical part, a student may receive an appointment card for military exercises. This is the practical part carried out in selected military units and military training units. This part of the Academic Legion training is carried out for six weeks during holiday breaks. It consists of two blocks:

(1) basic training, which lasts 21 days and concludes with an examination, followed by taking the oath of military service;

(2) non-commissioned officer training, which lasts 21 days and ends with an examination, and subsequent appointment to the rank of reserve corporal.

Ultimately, the Academic Legion Programme also envisages the launch of an officer module for students who have completed non-commissioned officer training. It is also planned that students who complete the course preparing for the officer candidate examination with a positive result, after obtaining higher education, will be directed to military universities to take the officer candidate examination (Wojsko 2020).

Another form of contemporary defence education is the "Passport Programme for the cooperation of subunits of pro-defence organisations with military units of the Armed Forces of the Republic of Poland" (Bdsp 2020). The programme consists of support for the Polish defence system by taking advantage of the defence potential of social organisations of a pro-defence character. The aim of the Passport Programme is to raise the level of training in qualified pro-defence organisations so as to achieve the ability to cooperate with military units of the Polish Armed Forces. The programme is a response of the Ministry of Defence to the enormous interest in defence-related issues among pro-defence organisations, which are estimated to have around 100,000 members. The Passport programme includes:

(1) Five weekend training sessions;

(2) Five five-day specialised courses (command, communication, logistics, medical, SERE -Survival, Evasion, Resistance, Escape);

(3) Several days in a summer training camp;

(4) Testing of skills as part of a tactical exercise with the military.

It should be pointed out that the Passport Programme is open to any non-governmental pro-defence organisation which is registered in the National Court Register or in the register of ordinary associations, conducts statutory activity connected with defence or national security, has statutes, has its scope of activities approved by the Minister of National Defence or documents the submission of the statute for approval with the Minister of National Defence, remains neutral in political matters and acts independently of political parties or other organisations of a political nature. A given organisation may participate in the Programme more than once, and 
participation is limited to adults who hold Polish citizenship.

The Passport programme concludes with a certificate of the objectives achieved and the number of training points that are the result of the activities and various forms of testing of knowledge and skills, including during participation in military exercises. Thus, the certificate testifies to the preparation of a given pro-defence subunit for cooperation with the Polish Armed Forces (Bdsp 2020).

In sum, the Academic Legion and the Passport Programme operating in Poland are examples of forms of short military training for young people. They make it possible not only to impart knowledge and skills connected with military training, but also to increase the number of recruits for the Polish Armed Forces. They also make it possible to monitor personal potential, which can potentially be used in the event of diverse threats.

\section{Conclusions}

Important elements of contemporary defence education are security education - a subject in primary and secondary schools, military education - a subject in secondary schools realised in Certified Military Uniformed Classes, and the Academic Legion and Passport Programme - implemented among students. The current subject of security education prepares young people to behave appropriately and react in difficult and crisis situations that pose a threat to health and life. It thus serves to build non-military potential. Strengthening military potential, on the other hand, is supported by the defence education of young people conducted today in uniformed secondary schools, especially those participating in the "Programme of supporting secondary schools operating Certified Military Uniformed Classes". It is also supported by defence education provided to students in the Academic Legion and in the "Passport Programme to cooperation of subunits of pro-defence organisations with military units of the Polish Armed Forces".

The research shown here shows that the core security education curriculum does not constitute a solid basis for defence education. This, on the other hand, is realised well in classes with a uniformed services profile, whose curricula are conducive to achieving the defence objectives outlined by the legislator. Particularly appreciated are the programmes of the Ministry of National Defence in agreement with the Ministry of National Education, which introduce the additional subject of military education and other forms of defence education in the form of voluntary training for students called the Academic Legion or the cooperation of subunits of pro-defence organisations with military units of the Polish Armed Forces through the Passport Programme. The content presented here make it possible to characterise the system of defence education for Polish youth after 1989 and its transformations. It also allows a positive assessment of the multidimensional defence education of youth and the preparation of society to act for individual, social and national security.

On the basis of the results obtained, the following recommendations can be made:

(1) Every effort should be made to ensure that young people are equipped with knowledge, skills and attitudes that can be used in actions for the defence, protection and strengthening of national security. Therefore, constant supervision and evaluation of the content of the implemented programmes should be conducted.

(2) In considerations of defence education, attention should be paid to the educators themselves - teachers, instructors, pedagogues, leaders. The effectiveness of this process depends to a significant degree on their substantive and teaching competences, as well as their experience, knowledge, and skills. Therefore, efforts to raise the substantive and teaching competence of school and military educators are worthwhile.

(3) Systematic research on defence education needs to be prepared and carried out, with particular emphasis on the young people trained, the content of the implemented programme, the motivation of the organisers and participants, or the further preferences and life plans of these young people. This knowledge would be helpful for the ongoing diagnosis of military and non-military potential, monitoring its trends, as well as the possibility of using it in actions in support of national security in the broad sense. 


\section{References}

Araucz-Boruc, A. (2015). Bezpieczeństwo i obronność w edukacji młodzieży (Security and defense in youth education). Wydawnictwo Uniwersytetu Przyrodniczo-Humanistycznego.

Bdsp, (2020). Retrieved Semptember 11, 2020, from: http://bdsp.wp.mil.pl/pl/2.html

Cackowski, Z. (1999). Sprawy edukacji: szkoła, oświata, wychowanie (School, education, upbringing). EDUK FILOZ, $27,73-90$.

Diskienė, D., Paulienè, R. (2018). Leadership as an identity creation in the new leadership paradigm. Journal of Security and Sustainability Issues, 7(4), 741-751. https://doi.org/10.9770/jssi.2018.7.4(18)

Grenčíková, A., Guščinskienė, J., Španková, J. (2017). The role of leadership in motivating employees in a trading company. Journal of Security and Sustainability Issues, 7(2), 247-255. http://www.iea.org/publications/free_new_Desc.asp?PUBS_ID=1883

Gryz, J. (2004). System bezpieczeństwa Rzeczpospolitej Polskiej XXI wieku (The security system of the Republic of Poland in the 21st century). In Zagrożenia bezpieczeństwa państwa XXI wieku (p. 50). Wydawnictwo AON.

Hurbišová, P., Davidová, M. (2016). Towards enhanced security: education and development of military commanders within the Lithuanian and Austrian Armed Forces. Journal of Security and Sustainability Issues, 5(3), 311-322. https://doi.org/10.9770/jssi.2016.5.3

Islamgaleyev, A., Karibdzhanov, C., Petrova, M. (2020). Towards sustainable functioning of organizations via stakeholder focus: methodological and thematic review. Journal of Security and Sustainability Issues, 10(1), 163-174.

Journal of Laws of the Ministry of Education No. 8 item 38. Regulation No. 36 of the Minister of National Education of 29 October 1992 on the types of schools in which students are obliged to undergo civil defence training and the principles for the organisation of civil defence training classes in schools. Retrieved Semptember 1, 2020, from: https://isap.sejm.gov.pl/

Journal of Laws, 2002 No. 113 item 987. Regulation of the Minister of National Education and Sport of 27 June 2002 on the types of schools, the pupils of which are subject to compulsory defence training and the organisation of such training. Retrieved Semptember 16, 2020, from: https://isap.sejm.gov.pl/

Journal of Laws, 2009 No. 139 item 1131. Regulation of the Minister of Education of 28 August 2009 on the means for the implementation of security education. Retrieved Semptember 16, 2020, from: https://isap.sejm.gov.pl/

Journal of Laws, 2017, item 356. Regulation of the Minister of National Education on the core curriculum for pre-school education and the core general education primary school curriculum, including for students with moderate or severe intellectual disabilities, general education for first-degree trade schools, general education for special job training schools and general education for post-secondary schools. Retrieved Semptember 12, 2020, from: https://isap.sejm.gov.pl/

Journal of Laws, 2017, item 60. Act of 21 November 1967 on the Universal Duty to Defend the Republic of Poland. Retrieved Semptember 24, 2020, from: https://isap.sejm.gov.pl/

Kaliński, M. (2005). Tradycja i współczesność przysposobienia wojskowego młodzieży szkolnej (1st ed.). Wydawnictwo Adam Marszałek.

Laužikas, R., Dailydaite, S. (2013). Benefits of social capital for sustainable innovation capabilities: Journal of Security and Sustainability Issues, 2(3), pp. 85-97, DOI: - Szukaj w Google. https://doi.org/10.9770/jssi.2013.2.3(7)

Loshytskyi, M., Kostenko, O., Koropatnik, I., Karelin, V. (2020). Organizational competence of NATO information security policy. Journal of Security and Sustainability Issues, 9(3), 735-746. https://doi.org/10.9770/jssi.2020.9.3(1)

M.P. 2011 No. 14 item 149. Uchwała Centralnej Komisji do Spraw Stopni i Tytułów z dnia 28 stycznia 2011 r (Resolution of the Central Committee for Degrees and Titles of January 28, 2011). Retrieved October 2, 2020, from: http://prawo.sejm.gov.pl/isap.nsf/

Pieczywok, A. (2012). Edukacja dla bezpieczeństwa wobec zagrożeń i wyzwań współczesności. In wydawnictwo AON (Education for security in the face of contemporary threats and challenges. In publisher AON). Wydawnictwo AON. isbn: 9788375231977

Pilch, T. (1999). Zasady badań pedagogicznych. Wyd. Akademickie Żak. https://docer.pl/doc/x8sec80

Program 2020/21. Program Legii Akademickiej w Akademii Sztuki Wojennej w roku akademickim 2020/21 (The program of the Academic Legion at the Academy of Martial Arts in the academic year 2020/21). Retrieved Semptember 30, 2020, from: https://www. wojsko-polskie.pl/legia-akademicka/

Ropski, J. (2015). Edukacja dla bezpieczeństwa w polskiej szkole i możliwości jej doskonalenia (Education for safety in Polish schools and the possibility of its improvement). In Akademia Wychowania Fizycznego. AWF Katowice. ISBN 978-83-64036-43-9 
Sejm (2020). Retrieved October 2, 2020, from: http://prawo.sejm.gov.pl/isap.nsf/DocDetails.xsp?id=WDU20170000356

Smaliukiene, R. (2019). Sustainability issues in the military: genesis and prospects. Journal of Security and Sustainability Issues, 8(3), 19-32. http://www.iea.org/publications/free_new_Desc.asp?PUBS_ID=1883

Smaliukiene, R., Vidmante, G., Sibeko, A., Alekna, M. (2020). Civil-military cooperation in disaster preparedness: information sharing and support in Lithuania. Journal of Security and Sustainability Issues, 9(3), 1105-1116. https://doi.org/10.9770/jssi.2020.9.3(17)

Soboń, A. (2017). The building of the state defence capacity based on a territorial defence system. Defense Resources Management in the 21st Century, 12(November), 440-445. https://doi.org/ISSN 2248 - 2385; ISSN-L 2248 - 2385. Retrieved Semptember 11, 2020, from: http://www.codrm.eu/conferences/2017/Carte\%20CoDRM\%202017-modificat.pdf

Soboń, A. (2018). Needs of non-military defence resources in scope of education- dilemmas of XXI century. Defense Resources Management in the 21st Century, 13, 300-307. https://doi.org/ISSN 2248 - 2385; ISSN-L 2248 - 2385 Retrieved Semptember 23, 2020, from: http://www.codrm.eu/conferences/2018/Carte\%20CoDRM\%202018.pdf

Tumalavičius, V., Danilevica, A., Kokina, I. (2020). Issues of peculiarities of military education on different levels: the modern notion of legal preparation for cadets. Journal of Security and Sustainability Issues, 9(4), 1275-1282. https://doi.org/10.9770/jssi.2020.9.4(14)

Urych, I. (2019). Potencjał obronny klas wojskowych. Studium teoretyczno-empiryczne (Defense potential of military classes. Theoretical and empirical study). Warsaw (Poland). In Wydawnictwo Akademii Sztuki Wojennej. Akademia Sztuki Wojennej. Retrieved Semptember 19, 2020, from: https://depot.ceon.pl/bitstream/handle/123456789/17374/Urych_Potencjał_książka.pdf?sequence=1\&isAllowed=y

Urych, I. (2020). On Security Education in Poland. The Essence and Content of the Subject of Education. Safety \& Defense, 5(2), 22-27. https://doi.org/10.37105/sd.52

Wojciszko, M. (2014). Koordynacja i nadzór przygotowań obronnych w województwie (Coordination and supervision of defense preparations in the voivodeship). In G. Kwaśniak \& M. Wojciszko (Eds.), Oficyna wydawnicza PWSZ (pp. 167-190). Oficyna wydawnicza PWSZ Nysa. Retrieved Semptember 11, 2020, from: http://www.pwsz.nysa.pl/sitecontent/oficyna/przygotowania_obronne_panstwa. php

Wojsko (2020). Retrieved Semptember 4, 2020, from: http://wojsko-polskie.pl/pl/pages/pilotazowy-program-ochotniczego-szkoleniastudentow-legia-akademicka-1/

\section{About contributors:}

Andrzej SOBOŃ is Ph.D, Colonel of the Polish Army, Dean of the Faculty of National Security at War Studies University (WSU), Professor at the WSU. He holds a postdoctoral degree in social sciences in the discipline of security sciences. Research interests are related to non-military defence preparation, security education, organisation of armed forces.

ORCID ID: orcid.org/0000-0003-2540-2252

Ilona URYCH is the academic teacher, holds a postdoctoral degree in social sciences in the discipline of security sciences, professor at the War Studies University, Vice Dean for Student Affairs at the Faculty of National Security at the War Studies University, conducts trainings for civilian and military personnel in the area of pedagogical development as well as leadership and social communication. Research interests are related to education, security education, military education, leadership, social security and physical culture. ORCID ID: orcid.org/0000-0000-0003-4868-9460 